\title{
Performance of Pea Varieties in Different Altitude Ranges under North-Western Himalayan Region
}

\author{
Deepa Sharma $^{1 *}$, Aanchal Chauhan ${ }^{1}$ and Kumud Jarial ${ }^{2}$ \\ ${ }^{1}$ Department of Vegetable Science, ${ }^{2}$ Department of Plant Pathology \\ College of Horticulture and Forestry, Dr. Y S Parmar University of Horticulture and \\ Forestry, Neri, Hamirpur, HP 177001, India
}

*Corresponding author

\section{A B S T R A C T}

\section{Keywords \\ Garden pea, \\ Varieties, Pod yield, Quality, Altitudes}

\section{Article Info}

Accepted:

21 May 2020

Available Online:

10 June 2020
An experiment was conducted to evaluate the performance of nine pea varieties (PB-89, AP-3, AP-1, VL-7, Arkel, Bonneville, Arka Kartik, JM-2 and Palam Priya) on the farmer's fields at three altitudinal ranges viz. $600 \mathrm{~m}$ amsl, $1375 \mathrm{~m}$ amsl and $1800 \mathrm{~m}$ amsl in Chamba district of Himachal Pradesh. The experiment was laid out in randomized block design with three replications. Standard package and practices were followed for raising the crop as per the recommendations of the University. The results of the experiment revealed that all the varieties exhibited considerable variation for most of the parameters studied on different experimental locations. The effect of varieties, zones and interaction between them was found to be significant for most of the traits.PB-89 performed best at the lowest altitudinal range by having maximum green pods per plant (17.98), highest green pod weight $(5.97 \mathrm{~g})$, green pod length $(10.96 \mathrm{~cm})$, maximum number of branches per plant (18.35) and highest yield (186.11q/ha) in zone I. Variety VL-7 proved best for zone II with maximum number of branches per plant (15.98), number of pods per plant (17.94)and highest yield (183.89 q/ha) whereas, Palam Priya performed best in the zone III with maximum green pod length $(9.40 \mathrm{~cm})$, number of pods per plant (17.97) and pod yield (185.78q/ha).

\section{Introduction}

Pea is an important vegetable crop of India generally cultivated for its green pods. It is highly nutritive and rich in protein. It is used as a vegetable or in soup, canned frozen or dehydrated besides being cooked as a vegetable. Split grains of pea are widely used for dal. Pea straw is also used as nutritious fodder. In India peas are grown in an area of
543,000 ha with a production of 5345,000 MT, whereas in Himachal Pradesh the production is $277200 \mathrm{MT}$ from an area of 23650 ha (NHB, 2018). The agro climatic conditions determines the time of sowing of peas and their place in crop rotation. Himachal Pradesh has varied agro-climate and district Chamba represents all the four agro climatic zones as it has altitudes ranging from 690 to $2400 \mathrm{~m}$ amsl. The climate of the 
district is suitable for pea cultivation. Being a cool season crop, pea performs best in the temperature range of $10^{\circ} \mathrm{C}$ to $18^{\circ} \mathrm{C}$. However, ideal temperature for pea cultivation is $10^{\circ} \mathrm{C}$ to $30^{\circ} \mathrm{C}$. The flower and young pods are badly affected by frost. The time of sowing differ in different altitudes due to temperature variation and this also affect the performance of different varieties in different locations. Pea is generally sown in India during the Rabi season from the beginning of October to mid of November in the plains and from middle of March to end of May in the hills. Although a number of varieties of pea are available for cultivation but there is a lack of information for their suitability for cultivation in different altitudinal ranges. The present study was envisaged to evaluate the performance of major pea cultivars under different altitudinal ranges so as to assess their suitability for each zone.

\section{Materials and Methods}

The experiment was conducted to assess the performance of nine varieties of pea in different altitudes viz. $600 \mathrm{~m}$ amsl, $1375 \mathrm{~m}$ amsl and $1800 \mathrm{~m}$ amsl in Chamba district of Himachal Pradesh. Nine varieties of pea viz. PB-89, AP-3, AP-1, VL-7, Arkel, Bonneville, Arka Kartik, JM-2 and Palam Priya were planted in farmer's fields during Rabi season of 2016-17. Seeds were sown at a depth of 4$5 \mathrm{~cm}$ on $3 \times 3 \mathrm{~m}^{2}$ beds with row to row and plant to plant distance $60 \mathrm{~cm}$ and $7.5 \mathrm{~cm}$ respectively. The experiment was laid out in randomized block design with three replications. Standard package and practices were followed as per the recommendation of the university. The data were recorded on ten randomly taken plants for plant height $(\mathrm{cm})$, number of branches per plant, days to first flowering, days to first pod picking, number of pods per plant, pod weight $(\mathrm{g})$, pod length (cm), number of seeds per pod, pod yield per plant $(\mathrm{g})$, pod yield per plot $(\mathrm{kg})$, pod yield per hectare (q/ha), shelling percentage $(\%)$ and total soluble solids ( ${ }^{\circ}$ Brix). Yield was recorded on plot basis. The mean values over the replications were statistically analyzed as per the standard statistical procedures (Panse and Sukhatme, 1997).

\section{Results and Discussion}

\section{Growth parameters}

The findings pertaining to growth parameters viz., plant height, number of branches per plant, days to first flowering and days to first pod picking indicated significant influence of different varieties, zones and their interactions as evident from the Table 1 .

All the varieties had shown significant variation for plant height. Maximum plant height was recorded in variety Arka Kartik $(75.13 \mathrm{~cm})$ which was statistically at par with Azad Pea $1(72.06 \mathrm{~cm})$. Minimum plant height was observed in variety Arkel $(51.16 \mathrm{~cm})$ which was statistically at par with Azad Pea $3(53.88 \mathrm{~cm})$. Among the different zones the effect was significant for plant height. Maximum plant height was observed in zone III $(70.62 \mathrm{~cm})$ and minimum in zone I (59.08 $\mathrm{cm})$. The effect of variety $\times$ zone interactions was also found to be significant with maximum plant height of variety Arka Kartik $(80.39 \mathrm{~cm})$ at zone III and minimum height of variety Arkel $(46.16 \mathrm{~cm})$ at zone I. A continuous increase in plant height in almost all the varieties was observed with increase in altitude as evident from Fig. 1. This may be due to environment conditions favorable to pea cultivation in higher hills. Similar results have also been reported by previous workers Bozoglu et al., (2007), Shah et al., (2016). Different responses to plant height can also be due to genetic characteristic of genotypes and adaptability to a particular environment. Since the genotype Arkel was earlier in flowering, so these had little time for attaining vegetative 
growth, reserved food materials diverted to sex expression, resulting in dwarfishness. The dwarf plant which could not benefit from prevailing climatic condition showed less adaptability in tested area. These finding shows resemblance with those reported by Ishtiaq et al., (1996); Khan et al., (2013).

Varieties showed significant variation with regard to number of branches per plant in garden pea. Maximum number of branches per plant was observed in variety PB89(15.73) which was at par with Palam Priya (14.91) whereas, minimum number of branches were observed in variety AP-1 (10.97) which was at par with Arka Kartik, AP-3, JM-2 and Arkel. The effect of different zones was found to be non-significant for this trait. Among the interaction of variety $\times$ zones the effects were found to be significant. Variety PB-89 (18.35) recorded maximum number of branches per plant in zone $I$ as evident from Fig. 2, whereas VL-7(15.98) and Palam Priya (16.32) showed maximum number of branches per plant in zone II and zone III respectively. The minimum number of branches was found in AP-1 at all the three zones. Variation could be due to genetic variability of different germplasm or due to climatic condition. Similar results were elucidated by Wadan et al., (1993).

The effects of varieties, zones and interaction between them was found to be significant with regard to days to first flower initiation and days taken to first pod picking in garden pea. Variety Arkel had taken minimum days to flowering (43.13) and was at par with JM-2 (46.51), whereas variety Bonneville (52.67) took maximum days to flower and was found at par with Arka Kartik (52.01), Palam Priya (50.85) and PB-89 (50.66). Between the zones days taken to first flowering was maximum in zone III (58.79) and minimum in zone I (37.53). Among the interaction earliest first flower initiation was observed in variety
Arkel (37.53, 43.21, and 48.66) and maximum days to first flower initiation were taken by variety Bonneville (47.45, 51.76, 58.79) at all the three locations. Variety Bonneville was found late in maturity with maximum days taken to first picking (78.21) and it was at par with Arka Kartik (76.83) and Palam Priya (74.13). Variety Arkel found to be earlier with minimum days taken to first pod picking (59.13) and it was found at par with VL-7 (62.19). Among variety $\times$ zone interaction variety Bonneville (83.92) in zone III and variety Arkel (52.32) in zone I had shown maximum and minimum day taken to first pod picking respectively. The days taken to first pod picking were found to be maximum in zone III (77.45) and minimum in zone I (62.04). The cultivars taking minimum number of days to flowering are comparatively early maturing than other cultivars, from the farmers point of view such cultivars seems to be more desirable because early flowering means early crop maturity.

It was also observed that days to first flowering in a particular variety varied with respect to the altitude of the different zones. As seen from Fig. 3 at lower altitude a variety take less number of days to flowering as compared to higher altitude. This may be due to different environmental conditions in different zones and high level of UV radiations at higher altitudes under study. At higher altitudes flowering was delayed by 25 days when exposed to UV radiations (Roro et al., 2016). Pea cultivars have a sufficiently wide range of duration of vegetative period and their consequent phases (flowering, maturation etc.). The duration of vegetative period corresponds to agro-climatic peculiarities of the area of their cultivation. Days to flowering has positive relation with days to first pod picking. These results are supported with those of Agarwal et al., (2006). 
Table.1 Performance of pea varieties at different zones with respect to growth parameters

\begin{tabular}{|c|c|c|c|c|c|c|c|c|c|c|c|c|c|c|c|c|}
\hline \multirow[t]{2}{*}{ Variety } & \multicolumn{4}{|c|}{ Plant height (cm) } & \multicolumn{4}{|c|}{ No. of branches/ plant } & \multicolumn{4}{|c|}{ Days to first flowering } & \multicolumn{4}{|c|}{ Days to first pod picking } \\
\hline & Zone I & Zone II & Zone III & Mean & Zone I & Zone II & Zone III & Mean & Zone I & Zone II & Zone III & Mean & Zone I & Zone II & Zone III & Mean \\
\hline PB-89 & 59.87 & 61.32 & 67.97 & 63.05 & 18.35 & 15.51 & 13.32 & 15.73 & 46.28 & 50.31 & 56.28 & 50.66 & 58.05 & 68.32 & 75.05 & 67.14 \\
\hline Azad Pea -3 & 47.38 & 55.87 & 58.39 & 53.88 & 13.10 & 12.51 & 12.53 & 12.71 & 39.95 & 49.73 & 54.49 & 48.06 & 60.58 & 71.62 & 79.53 & 70.58 \\
\hline Azad Pea -1 & 67.35 & 71.45 & 77.38 & 72.06 & 10.34 & 11.21 & 11.35 & 10.97 & 38.46 & 49.95 & 56.87 & 48.43 & 57.12 & 63.11 & 80.62 & 66.95 \\
\hline VL-7 & 57.49 & 65.79 & 72.21 & 65.16 & 12.42 & 15.98 & 12.57 & 13.66 & 39.34 & 48.37 & 54.09 & 47.27 & 55.53 & 62.34 & 68.71 & 62.19 \\
\hline Arkel & 46.16 & 50.79 & 56.53 & 51.16 & 12.86 & 11.42 & 11.97 & 12.08 & 37.53 & 43.21 & 48.66 & 43.13 & 52.32 & 59.29 & 65.78 & 59.13 \\
\hline Bonneville & 56.82 & 65.24 & 74.57 & 65.54 & 13.74 & 12.35 & 15.38 & 13.82 & 47.45 & 51.76 & 58.79 & 52.67 & 72.39 & 78.32 & 83.92 & 78.21 \\
\hline Arka Kartik & 73.25 & 71.75 & 80.39 & 75.13 & 10.37 & 11.83 & 12.96 & 11.72 & 47.32 & 51.55 & 57.17 & 52.01 & 70.52 & 76.42 & 83.57 & 76.83 \\
\hline JM-2 & 64.25 & 64.57 & 73.38 & 67.40 & 12.01 & 13.62 & 12.41 & 12.68 & 40.66 & 45.62 & 53.25 & 46.51 & 65.32 & 70.59 & 78.21 & 71.37 \\
\hline Palam Priya & 59.12 & 70.27 & 74.75 & 68.05 & 13.90 & 14.51 & 16.32 & 14.91 & 44.81 & 50.92 & 56.82 & 50.85 & 66.52 & 74.21 & 81.65 & 74.13 \\
\hline Mean & 59.08 & 64.12 & 70.62 & 64.60 & 13.25 & 13.28 & 13.32 & 13.28 & 42.42 & 49.05 & 55.16 & 48.88 & 62.04 & 69.36 & 77.45 & 69.61 \\
\hline CD & \multicolumn{3}{|c|}{$\begin{array}{l}\text { Variety } \\
\text { Zones } \\
\text { Variety x Zones }\end{array}$} & $\begin{array}{l}4.54 \\
3.05 \\
11.20\end{array}$ & \multicolumn{3}{|c|}{$\begin{array}{l}\text { Variety } \\
\text { Zones } \\
\text { Variety x Zones }\end{array}$} & $\begin{array}{l}1.80 \\
\mathrm{NS} \\
4.45\end{array}$ & \multicolumn{3}{|c|}{$\begin{array}{l}\text { Variety } \\
\text { Zones } \\
\text { Variety x Zones }\end{array}$} & $\begin{array}{l}3.55 \\
2.90 \\
8.28 \\
\end{array}$ & \multicolumn{3}{|c|}{$\begin{array}{l}\text { Variety } \\
\text { Zones } \\
\text { Variety x Zones }\end{array}$} & $\begin{array}{l}6.32 \\
4.89 \\
12.29 \\
\end{array}$ \\
\hline
\end{tabular}


Table.2 Performance of pea varieties at different zones with respect to yield contributing traits

\begin{tabular}{|c|c|c|c|c|c|c|c|c|c|c|c|c|c|c|c|c|c|c|c|c|}
\hline \multirow[t]{2}{*}{ Variety } & \multicolumn{4}{|c|}{ Number of pods/ plant } & \multicolumn{4}{|c|}{ Pods length (cm) } & \multicolumn{4}{|c|}{ Pod weight (g) } & \multicolumn{4}{|c|}{ Number of seeds/ pod } & \multicolumn{4}{|c|}{ Pod yield/ plant (g) } \\
\hline & Zone I & Zone II & Zone III & Mean & Zone I & Zone II & Zone III & Mean & Zone I & Zone II & Zone III & Mean & Zone I & Zone II & Zone III & Mean & Zone I & Zone II & Zone III & Mean \\
\hline PB-89 & 17.88 & 17.25 & 17.01 & 17.38 & 10.96 & 10.32 & 9.38 & 10.22 & 5.97 & 5.85 & 5.80 & 5.88 & 9.93 & 9.58 & 9.01 & 9.50 & 88.73 & 84.35 & 82.97 & 85.35 \\
\hline Azad Pea -3 & 14.78 & 13.21 & 12.20 & 13.40 & 6.27 & 6.95 & 7.98 & 7.07 & 3.51 & 4.01 & 5.07 & 4.20 & 7.11 & 6.25 & 5.83 & 6.40 & 61.21 & 59.81 & 60.38 & 60.47 \\
\hline Azad Pea -1 & 11.45 & 11.21 & 11.32 & 11.33 & 5.90 & 6.93 & 7.62 & 6.82 & 3.28 & 4.29 & 4.72 & 4.10 & 7.28 & 6.51 & 4.98 & 6.26 & 51.09 & 50.92 & 50.37 & 50.79 \\
\hline VL-7 & 16.91 & 17.94 & 16.89 & 17.25 & 6.46 & 8.15 & 7.87 & 7.49 & 4.57 & 5.57 & 5.69 & 5.28 & 6.25 & 7.53 & 5.64 & 6.47 & 76.92 & 77.75 & 75.92 & 76.86 \\
\hline Arkel & 16.68 & 15.56 & 14.98 & 15.74 & 6.37 & 7.53 & 8.72 & 7.53 & 3.9 & 5.02 & 5.70 & 4.87 & 7.01 & 6.92 & 5.26 & 6.40 & 59.56 & 56.75 & 58.35 & 58.22 \\
\hline Bonneville & 16.53 & 16.25 & 15.38 & 16.05 & 5.60 & 6.28 & 7.46 & 6.45 & 5.24 & 4.92 & 5.11 & 5.09 & 6.92 & 7.21 & 5.75 & 6.63 & 74.02 & 72.52 & 73.75 & 73.43 \\
\hline Arka Kartik & 11.22 & 13.32 & 13.11 & 12.58 & 5.42 & 5.87 & 7.00 & 6.10 & 3.27 & 3.87 & 4.10 & 3.75 & 4.90 & 6.78 & 5.92 & 5.87 & 56.27 & 58.53 & 57.87 & 57.56 \\
\hline JM-2 & 15.79 & 16.64 & 16.74 & 16.39 & 4.71 & 5.68 & 6.34 & 5.58 & 3.01 & 4.12 & 4.80 & 3.98 & 5.10 & 7.35 & 6.01 & 6.15 & 62.96 & 63.95 & 55.99 & 60.97 \\
\hline Palam Priya & 16.71 & 17.37 & 17.97 & 17.35 & 7.48 & 8.38 & 9.40 & 8.42 & 5.66 & 5.75 & 5.82 & 5.74 & 6.73 & 8.92 & 9.86 & 8.50 & 79.95 & 78.82 & 81.32 & 80.03 \\
\hline Mean & 15.24 & 15.42 & 15.07 & 15.27 & 6.57 & 7.34 & 7.97 & 7.30 & 4.49 & 4.86 & 4.96 & 4.81 & 6.47 & 6.95 & 7.45 & 6.96 & 69.91 & 67.64 & 66.67 & 68.07 \\
\hline CD & $\begin{array}{l}\text { Variet } \\
\text { Zones } \\
\text { Variet }\end{array}$ & x Zones & & $\begin{array}{l}2.13 \\
\text { NS } \\
6.93\end{array}$ & $\begin{array}{l}\text { Variet } \\
\text { Zones } \\
\text { Variet }\end{array}$ & Zones & & $\begin{array}{l}3.52 \\
2.60 \\
7.48\end{array}$ & $\begin{array}{l}\text { Variety } \\
\text { Zones } \\
\text { Variety }\end{array}$ & x Zones & & $\begin{array}{l}1.15 \\
0.29 \\
1.31\end{array}$ & $\begin{array}{l}\text { Variety } \\
\text { Zones } \\
\text { Variety }\end{array}$ & X Zones & & $\begin{array}{l}.40 \\
.77 \\
.20\end{array}$ & $\begin{array}{l}\text { Variety } \\
\text { Zones } \\
\text { Variety }\end{array}$ & x Zones & $\begin{array}{l}8.7 \\
\mathrm{~N} \\
10\end{array}$ & \\
\hline
\end{tabular}


Table.3 Performance of pea varieties at different zones with respect to yield and quality traits

\begin{tabular}{|c|c|c|c|c|c|c|c|c|c|c|c|c|c|c|c|c|}
\hline \multirow[t]{2}{*}{ Variety } & \multicolumn{3}{|c|}{ Pod yield/ plot (kg) } & & \multicolumn{4}{|c|}{ Pod yield/ hectare (quintals) } & \multicolumn{4}{|c|}{ TSS Content ( $\left.{ }^{\circ} \mathrm{brix}\right)$} & \multicolumn{4}{|c|}{ Shelling percentage $(\%)$} \\
\hline & Zone I & Zone II & Zone III & Mean & Zone I & Zone II & Zone III & Mean & Zone I & Zone II & Zone III & Mean & Zone I & Zone II & Zone III & Mean \\
\hline PB-89 & 17.61 & 16.08 & 15.98 & 16.56 & 186.11 & 180.67 & 181.22 & 182.67 & 17.20 & 17.01 & 17.25 & 17.15 & 51.06 & 52.32 & 53.32 & 52.23 \\
\hline Azad Pea -3 & 10.71 & 13.51 & 13.42 & 12.55 & 119.15 & 150.11 & 149.11 & 139.46 & 16.25 & 16.27 & 16.32 & 16.27 & 43.73 & 45.29 & 49.78 & 46.27 \\
\hline Azad Pea -1 & 10.24 & 10.62 & 11.19 & 10.68 & 102.56 & 105.33 & 107.33 & 105.07 & 16.59 & 16.35 & 16.58 & 16.51 & 43.03 & 44.21 & 48.37 & 45.20 \\
\hline VL-7 & 14.12 & 15.45 & 14.61 & 14.73 & 180.25 & 183.89 & 179.56 & 181.23 & 16.90 & 17.01 & 16.87 & 16.93 & 52.16 & 51.11 & 50.78 & 51.35 \\
\hline Arkel & 11.21 & 11.5 & 12.3 & 11.67 & 125.62 & 127.78 & 124.67 & 126.02 & 17.11 & 16.95 & 17.01 & 17.02 & 42.51 & 43.25 & 44.87 & 43.54 \\
\hline Bonneville & 13.87 & 16.88 & 14.98 & 15.24 & 163.02 & 169.78 & 164.02 & 165.61 & 17.23 & 17.85 & 16.69 & 17.26 & 43.17 & 42.92 & 47.91 & 44.67 \\
\hline Arka Kartik & 10.54 & 10.01 & 11.75 & 10.77 & 112.44 & 115.33 & 116.56 & 114.78 & 17.05 & 16.83 & 16.88 & 16.92 & 42.79 & 41.52 & 41.75 & 42.02 \\
\hline JM-2 & 10.86 & 11.02 & 11.26 & 11.05 & 132.67 & 129.44 & 131.78 & 131.30 & 17.57 & 17.71 & 17.82 & 17.70 & 43.75 & 50.01 & 51.74 & 48.50 \\
\hline Palam Priya & 15.51 & 15.96 & 16.74 & 16.07 & 178.89 & 180.33 & 185.78 & 181.67 & 17.34 & 17.94 & 17.46 & 17.58 & 50.51 & 51.52 & 51.73 & 51.25 \\
\hline Mean & 13.93 & 13.45 & 13.97 & 13.62 & 144.34 & 144.61 & 146.56 & 143.87 & 17.03 & 17.10 & 16.99 & 17.04 & 45.21 & 46.23 & 48.37 & 47.23 \\
\hline CD & $\begin{array}{l}\text { Variety } \\
\text { Zones } \\
\text { Variety }\end{array}$ & Zones & & $\begin{array}{l}2.78 \\
\text { NS } \\
3.53 \\
\end{array}$ & $\begin{array}{l}\text { Variety } \\
\text { Zones } \\
\text { Variety }\end{array}$ & & & $\begin{array}{l}6.61 \\
\text { NS } \\
1.02\end{array}$ & $\begin{array}{l}\text { Variety } \\
\text { Zones } \\
\text { Variety }\end{array}$ & Zones & & & $\begin{array}{l}\text { Variety } \\
\text { Zones } \\
\text { Variety }\end{array}$ & x Zones & & $\begin{array}{l}4.82 \\
\text { NS } \\
4.27\end{array}$ \\
\hline
\end{tabular}




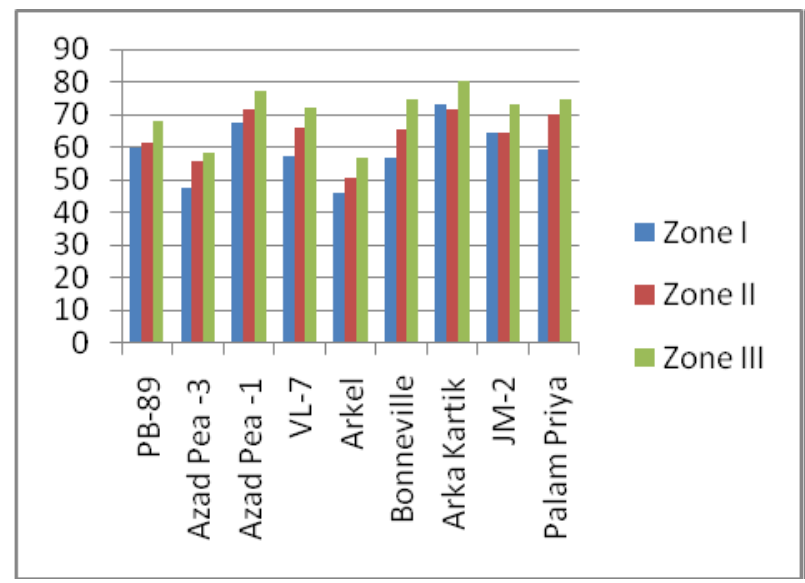

Figure 1: Plant Height

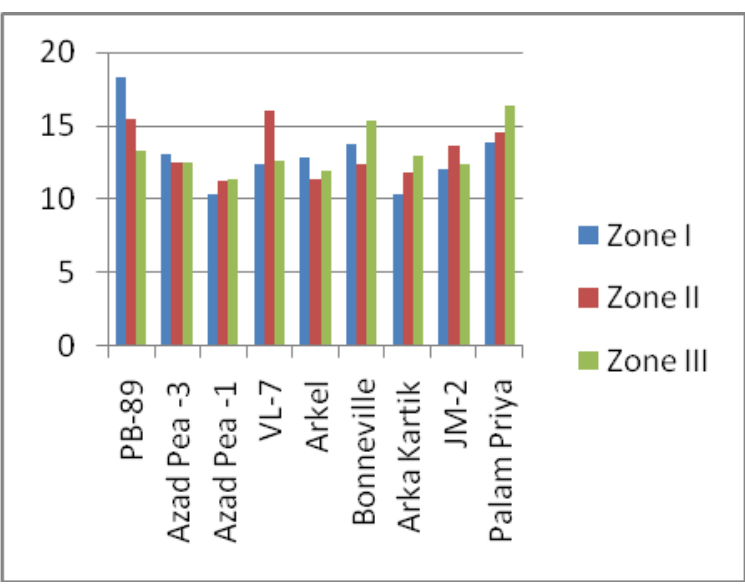

Figure 2: No. of Branches per Plant
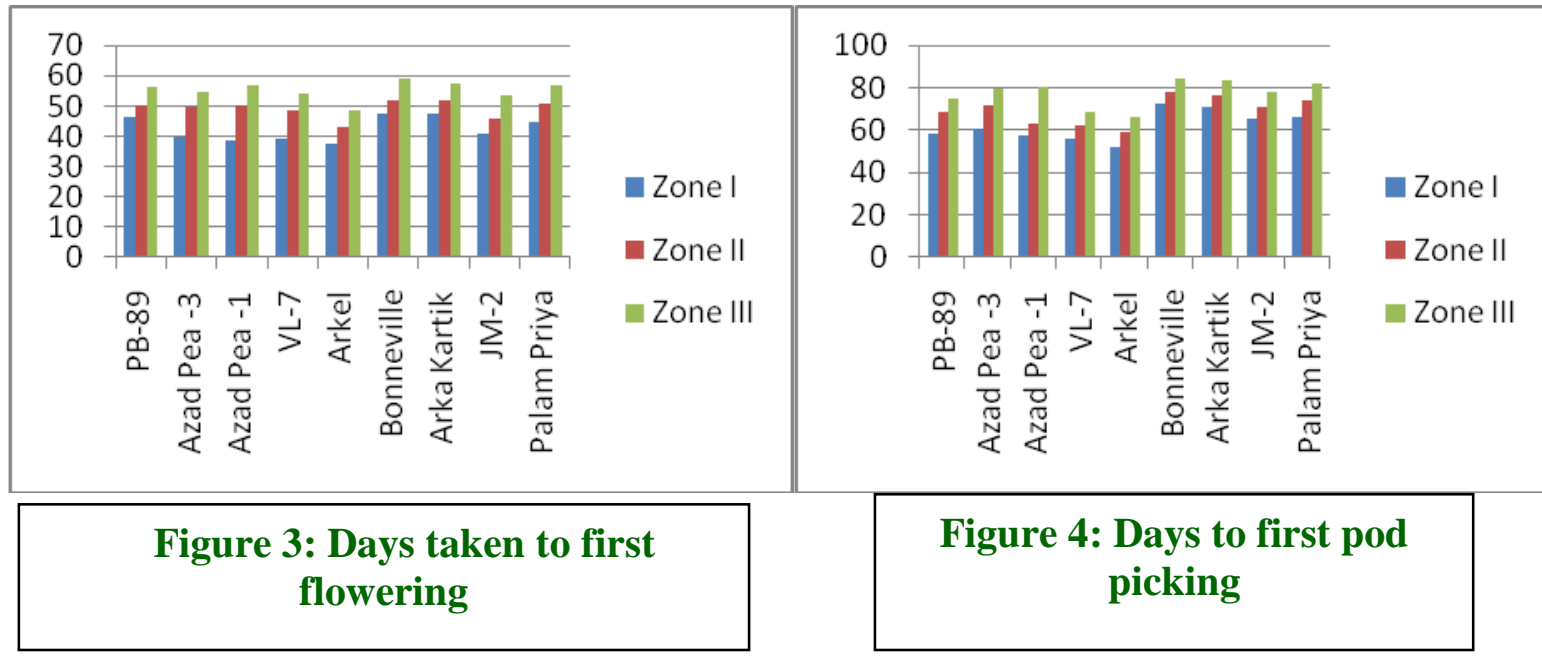

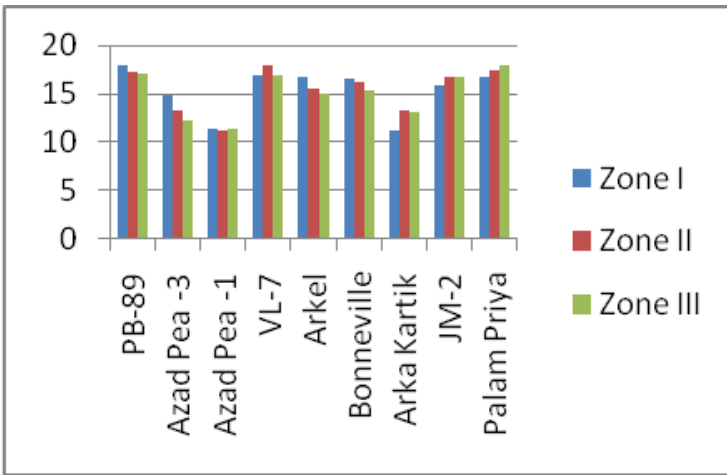

Figure 5: Number of pods per plant

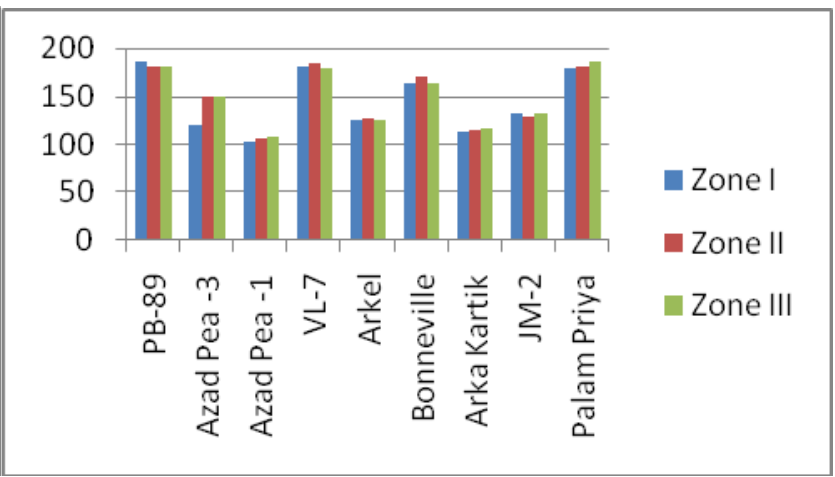

Figure 6: Pod yield per hectare 


\section{Yield and quality parameters}

Different varieties of garden pea were studied with respect to number of pods per plant, pod weight, pod length, number of seeds per pod, pod yield per plant, pod yield per plot, pod yield per hectare (q/ha), shelling percentage as well as TSS content. Perusal of data presented in Table 2 and 3 revealed significant effect of varieties, zones and their interaction on different yield and quality traits. There was significant difference among varieties of garden pea with respect to number of pod per plant. Maximum number of pods per plant was observed in variety PB-89 (17.38) which was at par with Palam Priya (17.35) and VL-7 (17.25). Minimum number of pods per plant was observed in variety Azad Pea-1 (11.33) followed by Arka Kartik (12.58) and Azad Pea-3 (13.40). The effect of different zones was non- significant for this trait. The variety $x$ zone interaction effect was significant with maximum number of pods per plant in variety PB-89(17.88), VL-7 (17.94) and Palam Priya (17.97) in zone I, zone II and zone III respectively. The lowest number of pods was observed under Arkel (11.22) in zone I and Azad Pea 1 (11.21 and 11.32) in zones II and III respectively. Number of pods per plant related to plant height. Vigorous varieties produced more pods while number of pods decreased with decrease in plant height, which might be attributed to genetic makeup of the plants. Some researchers observed number of pods per plant as the most useful yield component. These findings are in agreement with Khan et al., (2013) and Singh et al., (2017).

The effect of different varieties, zones and their interactions were found to be significant for pod length of garden pea. Among different varieties PB-89 $(10.22 \mathrm{~cm})$ showed maximum pod length which was at par with Palam Priya $(8.42 \mathrm{~cm})$, Arkel $(7.53 \mathrm{~cm})$ and VL-7 (7.49 $\mathrm{cm})$ whereas, minimum pod length was observed in JM-2 $(5.58 \mathrm{~cm})$. Among different zones maximum pod length was observed in zone III $(7.97 \mathrm{~cm})$ followed by zone II $(7.34$ $\mathrm{cm})$ and minimum in zone $\mathrm{I}(6.57 \mathrm{~cm})$. Among the interactions maximum pod length was found in variety PB-89 $(10.96 \mathrm{~cm})$ and minimum in variety JM-2 $(4.71 \mathrm{~cm})$ in zone $\mathrm{I}$. In general, pod size is a varietal character, but it is also affected by vigour of plant. Greater availability of nutrients especially during pod formation and development stages of more vigorous pea varieties might have translocated maximum of its reserved food material towards pod formation and development. Similar results were also reported by Khan et al., (2013) and Kumawat et al., (2018).

Different varieties of garden pea showed significant difference in green pods weight in all the locations. Among the varieties PB-89 $(5.88 \mathrm{~g})$ showed maximum pod weight and it was found at par with Palam Priya $(5.74 \mathrm{~g}$ ), VL-7 (5.28g) and Bonneville (5.09g). The effect of different zones was significant with maximum pod weight $(4.96 \mathrm{~g})$ in zone III and minimum $(4.49 \mathrm{~g})$ in zone $\mathrm{I}$. The variety $\times$ zone interactions were also found to be significant for this trait. Maximum pod weight was found in case of variety PB-89 $(5.97 \mathrm{~g})$ under zone I and minimum pods weight was recorded with JM-2 (3.01g) in zone I. This variation might be due to the inherent potential of cultivars and their interaction with soil and climatic conditions. Similar result also been reported by Khichi et al., (2016).

Number of seeds per pod indicated significant effect of different varieties, zones and variety $\times$ zone interactions on garden pea. Variety PB-89 (9.50) showed maximum number of seeds per pod which was at par with Palam Priya (8.50). Minimum number of seeds per pod was observed in variety Arka Kartik (5.87). Among the three zones zone III showed maximum number of seeds per pod 
(7.45) and zone I showed minimum number of seeds per pod (6.47). Variety $\times$ zone interactions showed maximum number of seed per pod in variety PB-89 (9.93) in zone I whereas, minimum number of seed per pod was observed with Arka Kartik (4.90) in zone I. Pod length has positive relationship with number of seed per pod. These results are similar to those of Arshad et al., (1998) who observed that numbers of seeds are correlated with pod length. The more is the pod length, the more is number of seeds and vice versa. The possible reason of less number of seeds per pod may be that environment was not suitable at the time of pollination and fertilization. These findings agree with Ofga et al., (2017). The effects of varieties and variety $\times$ zone interactions were found significant for pod yield per plant but effect of different zones was found to be nonsignificant. Among different varieties PB-89 $(85.35 \mathrm{~g})$ showed maximum pod yield per plant and it was at par with varieties Palam Priya $(80.03 \mathrm{~g})$ and VL-7 (76.86g). Variety $\times$ zone interactions showed maximum pod yield per plant for PB-89 (88.73g) in Zone I and minimum pod yield per plant was observed with A P-1(50.37g) at Zone III. Yield is a complex character determined by the interaction of many heritable characters with soil, climate and agronomic conditions. Maximum yield requires maximum vegetative growth during crop establishment. Similar findings have been reported by Alam et al., (2010).

The effect of varieties and variety $\times$ zone interactions were significant for pod yield per plot as well as for pod yield per hectare whereas the effect of zones was found to be non-significant for these traits. Pod yield per plot revealed maximum values with PB-89 $(16.56 \mathrm{~kg})$ which was at par with Palam Priya (16.07 kg) and minimum value was observed for Azad Pea $1(10.68 \mathrm{~kg})$ and it was statistically at par with Arka Kartik $(10.77 \mathrm{~kg})$.
Among the interaction effect maximum yield per plot was observed with PB-89 $(17.61 \mathrm{~kg})$ in zone I and minimum in Azad Pea 1(10.24 $\mathrm{kg}$ ) in zone I. Green pod yield per hectare revealed maximum values with PB-89 $(182.67 \mathrm{q})$ and it was statistically at par with Palam Priya (181.67 q) and VL-7(181.23). Among the interactions of variety $\times$ zones maximum and minimum yield per hectare was found inPB-89 (186.11 q) and Azad Pea 1 (102.56) in zone I respectively. More yields in different genotypes may be due to optimum plant survival, long and more number of seeds per pod, which ultimately contributed significantly towards final yield. The performance of a cultivar mainly depends on interaction of genetic makeup and environment. These findings are in agreement with Arshad et al., (1998). The effect of varieties was significant whereas effect of zones and variety $\times$ zones interaction showed non-significant effects on total soluble solids. Different varieties of garden pea exhibited significant difference in total soluble solids (TSS). Highest TSS was observed in variety JM-2 (17.70 brix) which was followed by Palam Priya (17.58 brix), Bonneville (17.26 brix) and PB-89 (17.15 ${ }^{\circ}$ brix). Minimum TSS was recorded in Azad pea-3 (16.27 ${ }^{\circ}$ brix).

Different varieties of garden pea exhibited significant difference in shelling percentage. Highest shelling percentage was observed in variety PB-89 (52.23\%) which was followed by VL-7 $(51.35 \%)$ and Palam Priya $(51.25 \%)$ with at par performance. Minimum shelling percentage was recorded in Arka Kartik $(42.02 \%)$. The interaction effect was also found significant for this trait with maximum shelling percentage $(53.32 \%)$ of PB-89 at zone III and minimum (41.52\%) in Arka Kartik at zone II. Similar findings have also been reported by Chaudhary et al., 2004) and Agarwal et al., (2006). 
In conclusion, there was a considerable variation among all the genotypes for most of the parameters studied on different experimental sites. PB-89 performed best at the lowest altitudinal range by having maximum green pods per plant, highest green pod weight, green pod length, maximum number of branches per plant and highest yield in zone I. Variety VL-7 proved to be the best performer for zone II by having maximum number of branches per plant, green pods per plant, seed yield per plantand highest yield whereas, Palam Priya performed best in the zone III with maximum number of green pods per plant, green pod weight and green pod yield.

\section{References}

Agarwal, A., Gupta, S. and Ahmed, A. 2006. Performance of garden pea (Pisum sativum L.) cultivars in high altitude cold desert of Ladakh. Indian J. Agric. Sci., 76(12): 713-715.

Alam, M. K., Uddin, M. M., Ahmed, M., Latif, M. A. and Rahman, M. M. 2010. Growth and green pod yield of garden pea varieties under different nutrient levels. J. Agrofor. Environ. 4 (1): 105-107.

Arshad, M., Hussain, S. A., Ali, S. A. N., Muhammad, N. and Ziaullah. 1998. Screening of pea (Pisum sativum L.) cultivars in Kohat valley. Sarhad J. Agric. 14(6): 559-562.

Bozoglu, H. E., Peksen, A. and Gulumser, A. 2007. Determination of the yield performance and harvesting periods of fifteen pea (Pisum sativum L.) cultivars sown in autumn and spring. Pak. J. Bot.39(6): 2017-2025.

Chaudhary, H., Soft, A. A. and Venna, M. K. 2004. Genetic variability in pea under temperate environment of Kashmir. (in) Book of Abstracts. First Indian Horticulture Congress on Improving
Productivity; Quaiity, Post-harvest Management and Trade in Horticultural Crops, IARI, New Delhi, 6-9 November 2004, p 55.

Ishtiaq, M., Ahmad, Z. and Shah, A. 1996. Evaluation of exotic cultivars of pea in Peshawar valley. Sarhad J. Agric.13: 425-431.

Khan, T. N., Ramzan, A., Jillani, G. and Mehmood, T. 2013. Morphological performance of peas (Pisum sativum L.) genotypes under rainfed conditions of potowar region. J. Agric. Res., 51(1): 51-60.

Khichi,P., Chandan, P.M., Chauhan, J., Srinivas, J. and Bhagat, M. 2016. Varietal evaluation of garden pea under semi-arid conditions of Vidharba region. Int. J. Farm. Sci.6(1): 20-24.

Kumawat, P.K., Singh, P., Singh, D., Mukherjee, S. and Kumawat, M. 2018. Study on correlation and path analysis for green pod yield and its contributing traits in vegetable pea (Pisum sativum L.). Int. J.Curr. Microbiol. App. Sci., 7(6): 3497-3502.

National Horticulture Board (NHB). 2018. http/www.nhb.gov.in

Ofga, B. and Petros, Y. 2017. Genetic variability and association among agronomic characters in selected field pea (Pisum sativum L.) genotypes at Bale zone, Sinana Research Center, Oromia Region, Ethopia. Int. J. Genet. Genom. 5(6): 63-75.

Panse, V.G. and Sukhatme, P. V. 1997. Statistical methods for agricultural workers, ICAR, New Delhi. $2^{\text {nd }}$ Edn. p. 381.

Roro, A.G., Terfa, M. T., Solhaug K. A., Tsegaye, A., Olsen, J. E. and Torre, S. 2016. The impact of UV radiation at higher altitudes close to the equator on morphology and productivity of pea (Pisum sativum L.) in different 
seasons. South Afri. J. Bot. 106(9): $119-128$.

Shah, B. H., Hamid, F.S., Shams- U- Islam, Fayaz, A., Sohail, A. and Khan, N. 2016. Evaluation of different pea (Pisum sativum L.) genotypes for yield and other attributes at Shinkiari, Mansehra. Pak. J. Agri. Res., 29(4):323-330.

Singh, B. S., Sutradhar, M., Singh, A.K. and
Singh, S. K. 2017. Evaluation of genetic variability, correlation and path coefficients analysis for yield attributing traits in field peas. J.Agri. Ext. Rural Dev. 8(3):19-28.

Wadan, D., Khan, M. and Majeed, A. 1993. Performance of pea cultivars in various agro climatic conditions of Swat. Sarhad J. Agric., 9(2): 139-143.

\section{How to cite this article:}

Deepa Sharma, Aanchal Chauhan and Kumud Jarial. 2020. Performance of Pea Varieties in Different Altitude Ranges under North-Western Himalayan Region. Int.J.Curr.Microbiol.App.Sci. 9(06): 3292-3302. doi: https://doi.org/10.20546/ijcmas.2020.906.392 